\title{
Effects of combined alpha and beta adrenoceptor blockade in patients with angina pectoris A double blind study comparing labetalol with placebo
}

\author{
ARSHED A QUYYUMI, * CHRISTINE WRIGHT, LORNA MOCKUS, \\ MARGARET SHACKELL, $†$ GEORGE C SUTTON,† KIM M FOX* \\ From the ${ }^{\star}$ National Heart Hospital, London; and †Hillingdon Hospital, Uxbridge, Middlesex
}

SUMMARY The effects of a combined alpha and beta receptor antagonist, labetalol, were investigated in 10 patients with chronic stable angina pectoris. The optimal dose was determined during an initial dose titration study when the patients were treated with $200 \mathrm{mg}, 400 \mathrm{mg}$, and $600 \mathrm{mg}$ (six patients) of labetalol a day. The effective dose was then compared with placebo in a double blind randomised study. The effects of the drug were monitored with angina diaries, treadmill exercise testing, and 48 hour ambulatory electrocardiographic ST segment monitoring. Plasma labetalol concentrations were measured during each treatment period. The mean effective antianginal dose of labetalol was 480 (SD 140) $\mathrm{mg} /$ day given by mouth twice a day. There was a dose related reduction in daytime and nocturnal heart rate, the frequency of pain was significantly reduced by $41 \%$, and exercise duration was significantly increased by $44 \%$ with labetalol when compared with placebo. The frequency and duration of the episodes of ST segment depression were significantly reduced by $56 \%$ and $73 \%$ respectively with labetalol. Adverse effects resulted in a reduction of the dose of labetalol in two patients. Thus labetalol is an effective agent in the treatment of angina pectoris.

Although beta adrenoceptor antagonists have become established in the treatment of patients with exertional angina pectoris, ${ }^{1}$ their role in treating angina at rest remains controversial since myocardial ischaemia in these circumstances is often thought to be secondary to reduction in myocardial blood flow, possibly as a result of coronary spasm..$^{23}$ As coronary vascular tone is mediated via both alpha (vasoconstrictive) and beta (vasodilative) adrenergic nerve endings ${ }^{4}$ pure beta adrenergic blockade may increase coronary tone not only directly but also indirectly by permitting unopposed alpha vasoconstrictor action. It seemed reasonable therefore to consider alpha blocking agents in the treatment of angina pectoris. ${ }^{56}$ Pure alpha blockers, however, were found to be unpredictable in patients with myocardial ischaemia because they tend to cause tachycardia. ${ }^{78} \mathrm{~A}$ safer and more predictable formulation was obtained by combining an alpha blocker with a beta blocker, which theoretically avoids the drawback of tachycardia and the potential

Requests for reprints to Dr A A Quyyumi, National Heart Hospital, Westmoreland Street, London W1.

Accepted for publication 15 October 1984 risks of exacerbating coronary spasm. ${ }^{9}$

Labetalol, 5-(1-hydroxy-2-[(1-methyl-3 phenylpropyl) amino] ethyl) salicylamide, has both beta and alpha receptor blocking properties. ${ }^{9-13}$ It has nonselective beta blocking actions, with competitive antagonism of both beta (cardiac) and beta $_{2}$ (bronchial and vascular) receptors with beta ${ }_{1}$ receptor blockade somewhat more prominent than beta ${ }_{2}$ blockade. ${ }^{9}$ Labetalol has partial beta ${ }_{2}$ agonist activity, some direct vasodilative activity, and membrane stabilising activity and is lipid soluble and excreted through the kidneys (50\%) after conjugation in the liver. 9 It is currently used as an antihypertensive agent in all grades of hypertension. ${ }^{14-16} \mathrm{~A}$ few studies have shown the effectiveness of labetalol in hypertension and angina. $5617-20$

This study was designed to assess the effects of labetalol in patients with angina pectoris using a double blind placebo controlled technique. Previous dose titration was carried out to determine the optimum dosage for each patient. In addition to the measurements of angina frequency and exercise capacity, we objectively assessed the magnitude, frequency, and duration of myocardial ischaemia during 
each treatment phase by means of ambulatory electrocardiographic ST segment monitoring.

\section{Patients and methods}

Ten patients (eight men, two women) aged 42 to 72 years with at least a three month history of chronic stable angina pectoris were studied. Eight patients had angiographically confirmed obstructive coronary artery disease and two a well documented history of myocardial infarction. Before the study all patients had been shown to develop chest pain and significant ST segment depression during treadmill exercise testing and ambulatory electrocardiographic monitoring. No patients had episodes of ST segment elevation. All patients had previously been treated with beta adrenoceptor antagonists.

\section{STUDY PHASES}

The study was divided into two phases.

Dose titration-Each patient was treated with labetalol twice daily. The total daily dose was $200 \mathrm{mg}$ for two weeks and $400 \mathrm{mg}$ for two weeks in all the patients and $600 \mathrm{mg}$ for two weeks in six patients. Patients kept angina diaries and had exercise testing and 48 hour ambulatory electrocardiographic ST segment monitoring performed at the end of each two week treatment period.

Double blind comparison-The optimum effective dose of labetalol for each patient was determined during the dose titration phase. The patients were then randomly allocated to treatment with this dose of labetalol for two weeks and placebo for two weeks in a double blind crossover manner. Assessment with angina diaries, exercise testing, ambulatory ST segment monitoring, and blood concentrations of labetalol was performed at the end of each treatment period.

\section{ANGINA DIARIES}

A detailed record of the time and frequency of chest pain and activity at the time of pain was kept throughout both phases of the study.

\section{EXERCISE TESTING}

All patients underwent incremental treadmill exercise testing according to the modified Bruce protocol ${ }^{21}$ at the end of each two week treatment period. Maximal symptom limited exercise tests were performed in which the 12 lead electrocardiogram was recorded at the end of each minute. Significant ST segment depression was defined as a depression of $\geqslant 1 \mathrm{~mm}$ in magnitude occurring $0.08 \mathrm{~s}$ after the $\mathrm{J}$ point which persisted for at least three consecutive beats.
AMBULATORY MONITORING

Forty eight hour ambulatory electrocardiographic monitoring was performed using a frequency modulated recorder (Oxford Medilog II, frequency response $0.05-40 \mathrm{~Hz}$ ). A two channel recording was obtained with bipolar leads CM5 and modified lead II. The magnetic tapes were read visually at 60 times normal speed (Oxford Medilog MA20 analyser), and the number, duration, and magnitude of ST segment changes were noted. Significant ST segment depression was defined as depression of $\geqslant 1 \mathrm{~mm}$ in magnitude occurring $0.08 \mathrm{~s}$ after the J point and persisting for at least one minute. An hourly heart rate trend was also obtained during each monitoring period. Patients underwent their normal daily activities during the $\mathbf{4 8}$ hour period of ambulatory monitoring in order to assess the effect of treatment under similar circumstances. The daytime heart rate was determined at the beginning of the exercise tests and the mean nocturnal heart rate calculated from the average of the hourly heart rates between 2400 and 0600 obtained during ambulatory monitoring.

\section{LABETALOL ASSAY}

The serum labetalol concentration was measured at the end of each two week treatment period throughout the dose titration and double blind phases of the study by a high performance liquid chromatography assay. This was used to assess patient compliance only since the samples were obtained 2-18 hours after the last dose of the drug.

\section{STATISTICAL ANALYSIS}

Results are expressed as mean and standard deviation. Discrete data were analysed using the Wilcoxon signed rank test for paired observations and was restricted to the double blind phase of the study.

\section{Results}

\section{DOSE TITRATION}

All patients were given the $200 \mathrm{mg} /$ day and the 400 $\mathrm{mg} /$ day doses of labetalol. Six patients did not become asymptomatic and were therefore given labetalol 600 $\mathrm{mg} / \mathrm{day}$. The dose allocation for the second phase of the study was ascertained from the history and ambulatory monitoring data.

Heart rate and blood pressure-Table 1 shows the effect of increasing doses of labetalol on the resting heart rate, blood pressure, and rate pressure product. There was a dose related reduction in the resting daytime heart rate and in both the systolic and diastolic arterial blood pressure (Table 1, Figure).

Angina frequency-Table 2 shows the frequency of chest pain associated with ST segment depression during the $\mathbf{4 8}$ hour ambulatory monitoring period and 
Table 1 Effect of labetalol on the resting heart rate, blood pressure, and rate-pressure product during the dose titration and double blind studies. Results are mean (standard deviation)

\begin{tabular}{|c|c|c|c|c|c|}
\hline & \multicolumn{2}{|c|}{ Heart rate (beats/min) } & \multicolumn{2}{|c|}{ Resting blood pressure (mm $\mathrm{Hg}$ ) } & \multirow[t]{2}{*}{ Rate-pressure product } \\
\hline & Daytime & Nocturnal & Systolic & Diastolic & \\
\hline \multicolumn{6}{|c|}{ Dose titration study } \\
\hline $\begin{array}{l}200 \\
400 \\
600(n=6)\end{array}$ & $\begin{array}{l}76(12) \\
70(15) \\
64(12)\end{array}$ & $\begin{array}{l}65(8) \\
64(11) \\
61(9)\end{array}$ & \multirow{2}{*}{$\begin{array}{c}130(17) \\
119(17) \\
116(12) \\
\text { Double blind study } \\
141(21)\end{array}$} & $\begin{array}{l}80(8) \\
81(8) \\
76(10)\end{array}$ & $\begin{array}{l}9900(2370) \\
8470(2510) \\
7500(2220)\end{array}$ \\
\hline $\begin{array}{l}\text { Placebo } \\
\text { Labetalol }\end{array}$ & $83(10)$ & $69(12)$ & & $94(13)$ & $11350(2380)$ \\
\hline$(480(140) \mathrm{mg})$ & $69(13)^{\star \star}$ & $64(10)^{\star}$ & $110(15)^{\star \star}$ & $75(10)^{\star \star}$ & $7900(1820)^{\star \star}$ \\
\hline
\end{tabular}

${ }^{\star} \mathrm{p}<0.05,{ }^{\star \star} \mathrm{p}<0.01$.

during the last seven days of each treatment period. All patients continued to have angina with labetalol $200 \mathrm{mg}$ a day. Three patients became free of pain with $400 \mathrm{mg} /$ day, although two of these had episodes of painless ST segment depression during monitoring. One patient had a systolic blood pressure of $95 \mathrm{~mm}$ $\mathrm{Hg}$ with labetalol $400 \mathrm{mg} /$ day but remained asymptomatic. Another patient was pain free with $400 \mathrm{mg} /$ day but had postural hypotension. Three of the six patients treated with $600 \mathrm{mg} /$ day had no pain during the last seven days or during the last 48 hour monitoring period, and the other three patients had a greatly decreased frequency of pain.

Exercise testing-Table 3 shows the duration of exercise, heart rate, and systolic blood pressure at the time of development of $1 \mathrm{~mm}$ planar or downsloping ST segment depression. The duration of exercise to 1 mm ST segment depression was increased in eight of

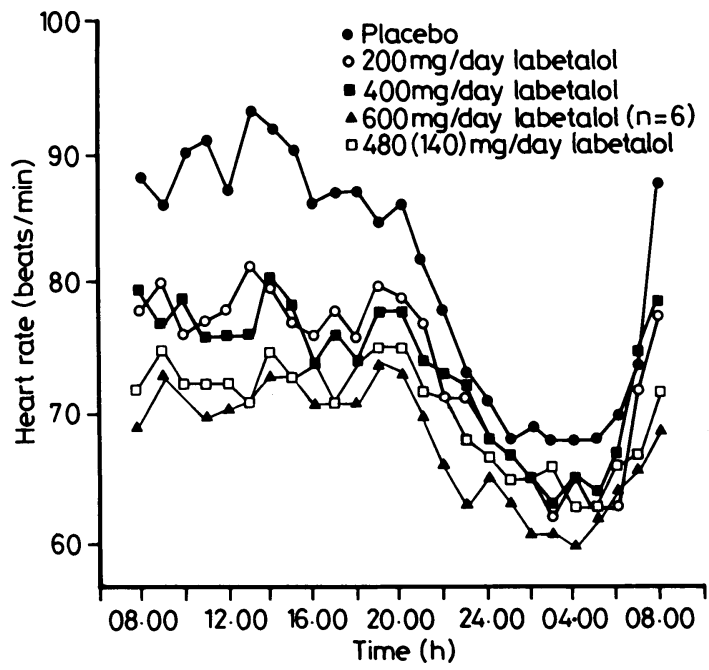

Figure Hourly heart rate changes during 24 hours of ambulatory monitoring with labetalol during the dose titration and double blind phases of the study. the 10 patients with $400 \mathrm{mg} /$ day, and the total exercise duration was increased in nine. With $600 \mathrm{mg} /$ day three of the six patients showed further improvement in total exercise capacity and duration of exercise to 1 $\mathrm{mm}$ ST depression. The other three patients exercised to the same workload as with the $400 \mathrm{mg} /$ day dose. A stepwise increase in beta blockade was evident with increasing doses of labetalol. The mean heart rate after three minutes of exercise was 100 (15) beats $/ \mathrm{min}$ with $200 \mathrm{mg} /$ day, 95 (12) beats $/ \mathrm{min}$ with $400 \mathrm{mg} /$ day, and 91 (13) beats/min with $600 \mathrm{mg} /$ day. Both the heart rate and systolic blood pressure at the onset of $1 \mathrm{~mm} \mathrm{ST}$ depression and at the end of the test tended to be lower with the higher doses of labetalol even though the workload achieved was greater (Table 3).

Ambulatory ST segment monitoring-Table 2 shows the number, duration, and magnitude of episodes of ST segment depression. Compared with labetalol 200 $\mathrm{mg} /$ day, $400 \mathrm{mg} /$ day produced a reduction in the number and duration of episodes of ST segment depression in four patients. With $600 \mathrm{mg} /$ day all six patients showed an improvement in the frequency or the duration of ischaemia.

Plasma labetalol concentration-All patients complied with drug treatment throughout the dose titration phase (Table 4).

\section{DOUBLE BLIND COMPARISON}

The optimum dose for the double blind phase of the study was $200 \mathrm{mg} /$ day in one patient, $400 \mathrm{mg} /$ day in four, and $600 \mathrm{mg} /$ day in five (mean 480 (140) $\mathrm{mg} /$ day). One patient developed severe and frequent chest pain during the placebo period, which was limited to five days.

Heart rate and blood pressure-The mean daytime resting heart rate, the mean nocturnal heart rate, and the mean systolic and diastolic arterial blood pressures were lower with labetalol than with placebo (Table 1). The daytime heart rate was lowered by a mean of $17 \%$ $(p<0.01)$, whereas the mean nocturnal heart rate was reduced by $7 \%(\mathrm{p}<0.05)$ with labetalol (Figure). 
Table 2 Frequency, magnitude, and duration of episodes of ST segment depression during each 24 hour period of ambulatory monitoring and the frequency of pain during the dose titration and double blind phases of the study. Results are mean (standard deviation)

\begin{tabular}{|c|c|c|c|c|c|}
\hline & \multicolumn{3}{|c|}{$S T$ segment depression } & \multirow{2}{*}{$\begin{array}{l}\text { No of painful } \\
\text { episodes of } S T \\
\text { depression }\end{array}$} & \multirow{2}{*}{$\begin{array}{l}\text { No of episodes } \\
\text { of pain/week }\end{array}$} \\
\hline & No of episodes & $\begin{array}{l}\text { Duration of episodes } \\
\text { (min) }\end{array}$ & $\begin{array}{l}\text { Mean maximum } \\
\text { magnitude }(\mathrm{mm})\end{array}$ & & \\
\hline \multicolumn{6}{|c|}{ Dose titration study } \\
\hline $\begin{array}{l}200 \\
400 \\
600(n=6)\end{array}$ & $\begin{array}{l}4.3(3.2) \\
4.7(3.9) \\
2.3(1.4)\end{array}$ & $\begin{array}{l}67(70) \\
72(65) \\
36(26)\end{array}$ & $\begin{array}{l}1.8(1.1) \\
2.0(1.2) \\
2.3(0.5) \\
e \text { blind study }\end{array}$ & $\begin{array}{l}1.2(1.3) \\
1.4(1.4) \\
0.2(0.3)\end{array}$ & $\begin{array}{l}13(12) \\
8(9) \\
2(3)\end{array}$ \\
\hline \multirow{2}{*}{$\begin{array}{l}\text { Placebo } \\
\text { Labetalol } \\
\quad(480(140) \mathrm{mg})\end{array}$} & $3.4(2.6)$ & $80(87)$ & $1.9(1.3)$ & $1.1(1.0)$ & $10(9)$ \\
\hline & $1.5(2.2)^{\star \star}$ & $22(50)^{\star \star}$ & $1.9(1.4)(\mathrm{NS})$ & $0.1(0.3)^{\star}$ & $5.9(8.8) \star \star$ \\
\hline
\end{tabular}

${ }^{\star} p<0.05,{ }^{\star \star} p<0.01, \mathrm{NS}$, not significant.

Angina frequency - When compared with placebo, labetalol at a mean dose of $480(140) \mathrm{mg} /$ day reduced the angina attack frequency by $41 \%(p<0.01)$. Chest pain was completely abolished in three patients. The frequency of chest pain was reduced in another five patients. One patient experienced the same frequency of pain during both the active treatment and placebo periods, while one patient had one more episode of pain with labetalol compared with placebo (Table 2).

Exercise testing-The duration of exercise before the development of ST segment depression was increased by $44 \%(p<0.01)$ after labetalol compared with placebo. The total duration of exercise was increased by $29 \%(p<0.01)$, and all patients showed an improvement in exercise capacity (Table 3 ).

Evidence of beta blockade was not only observed at rest, when the heart rate and blood pressure values were lower (Table 1), but was evident at each stage of exercise. After three minutes of exercise, mean heart rate had increased from 83 (10) beats/min to 95 (12) beats/min with placebo and from $69(13)$ beats/min to 80 (12) beats/min with labetalol. After six minutes' exercise, the heart rate had increased to 112 (14) beats/min $(n=8)$ with placebo and 93 (13) beats/min with labetalol. The mean heart rate and systolic blood pressure at the onset of $1 \mathrm{~mm} \mathrm{ST} \mathrm{segment} \mathrm{depression}$ and at the termination of exercise were significantly lower during labetalol treatment (Table 3) $(\mathbf{p}<0.01)$. The rate of increase in heart rate was not significantly different after three minutes of exercise with labetalol (11 (6) beats/min) compared with placebo (12 (4) beats/min). Nevertheless, the rate of increase in heart rate was significantly lower at six minutes of exercise in the eight patients who reached this level (increase of 32 (6) beats $/ \mathrm{min}$ ) with placebo and 25 (3) beats $/ \mathrm{min}$ with labetalol $(\mathrm{p}<0.05))$.

Ambulatory ST segment monitoring - Treatment with labetalol (480 (140) $\mathrm{mg} /$ day) abolished all episodes of ST segment depression in five patients and significantly reduced the frequency and duration of

Table 3 Duration of exercise and haemodynamics after treadmill exercise to $1 \mathrm{~mm} S T$ segment depression and at the termination of the test during the dose titration and double blind phases of the study. Results are mean (standard deviation)

\begin{tabular}{|c|c|c|c|c|c|c|c|c|}
\hline & \multicolumn{4}{|c|}{ Haemodynamics to $1 \mathrm{~mm} \mathrm{ST}$ depression } & \multicolumn{4}{|c|}{ Haemodynamics at termination } \\
\hline & $\begin{array}{l}\text { Exercise } \\
\text { duration } \\
\text { (min) }\end{array}$ & $\begin{array}{l}\text { Heart rate } \\
\text { (beats/min) }\end{array}$ & $\begin{array}{l}\text { Systolic blood } \\
\text { pressure } \\
(\mathrm{mm} \mathrm{Hg})\end{array}$ & $\begin{array}{l}\text { Rate-pressure } \\
\text { product }\end{array}$ & $\begin{array}{l}\text { Exercise } \\
\text { duration } \\
\text { (min) }\end{array}$ & $\begin{array}{l}\text { Heart rate } \\
\text { (beats/min) }\end{array}$ & $\begin{array}{l}\text { Systolic blood } \\
\text { pressure } \\
(\mathrm{mm} \mathrm{Hg})\end{array}$ & $\begin{array}{l}\text { Rate-pressure } \\
\text { product }\end{array}$ \\
\hline \multicolumn{9}{|c|}{ Dose titration study } \\
\hline $\begin{array}{l}\text { Labetalol (mg) } \\
200 \\
400 \\
600(n=6)\end{array}$ & $\begin{array}{l}5.1(1.7) \\
6.5(1.7) \\
7.2(1.3)\end{array}$ & $\begin{array}{l}110(19) \\
110(16) \\
107(15)\end{array}$ & $\begin{array}{l}149(26) \\
136(16) \\
138(27)\end{array}$ & $\begin{array}{l}16720(5040) \\
15090(3770) \\
14920(4450)\end{array}$ & $\begin{array}{l}6.4(2.2) \\
8.1(1.9) \\
8.7(1.5)\end{array}$ & $\begin{array}{l}122(21) \\
117(20) \\
115(22)\end{array}$ & $\begin{array}{l}152(28) \\
138(24) \\
138(36)\end{array}$ & $\begin{array}{l}18820(5900) \\
16570(5420) \\
16380(6325)\end{array}$ \\
\hline \multicolumn{9}{|c|}{ Double blind study } \\
\hline \multirow{2}{*}{$\begin{array}{l}\text { Placebo } \\
\text { Labetalol } \\
\quad(480(140) \mathrm{mg})\end{array}$} & $5 \cdot 4(2 \cdot 0)$ & $121(12)$ & $166(34)$ & $20440(5739)$ & $6 \cdot 8(1 \cdot 7)$ & $131(15)$ & $177(40)$ & $23560(7410)$ \\
\hline & $7.8(1.9)^{\star \star}$ & $110(15)^{\star \star}$ & $133(20)^{\star \star}$ & $14810(3590)^{\star \star}$ & $8.5(1.6)^{\star \star}$ & $114(15)^{\star \star}$ & $137(22)^{\star \star}$ & $15710(4180)^{\star \star}$ \\
\hline
\end{tabular}

$\star \star \mathrm{p}<0.01$. 
Table 4 Mean (SD) plasma labetatol concentration during the dose titration and double blind phases of the study

\begin{tabular}{lc}
\hline Dose & $\begin{array}{l}\text { Plasma labetalol } \\
\text { concentration }(\mu \mathrm{g} / \mathrm{l})\end{array}$ \\
\hline Labetalol (mg) & Dose titration study \\
200 & \\
400 & $40(17)$ \\
$600(\mathrm{n}=6)$ & $98(42)$ \\
Placebo & $197(110)$ \\
Labetalol (480 (140) $\mathrm{mg})$ & 0 \\
\hline
\end{tabular}

both painful and painless episodes of ST segment depression in the other five when compared with placebo $(p<0.01)$ (Table 2). The maximum magnitude of the episodes of ST segment depression was not significantly altered with labetalol, although the number of these episodes was lower (Table 2).

Plasma labetalol concentrations-All patients complied with the double blind phase of the trial, and Table 4 shows the serum labetalol concentrations.

Adverse effects-Five patients complained of leg fatigue and three intermittent claudication during labetalol treatment. One patient had episodes of postural hypotension with labetalol $400 \mathrm{mg} /$ day and was therefore randomised to receive $200 \mathrm{mg}$ /day. One patient complained of increased dyspnoea on exertion with $400 \mathrm{mg} /$ day compared with the lower dose. One patient developed an increase in the frequency of dreams and one had difficulty in micturition with labetalol treatment.

\section{Discussion}

Although beta adrenoceptor antagonists have become a mainstay in the treatment of angina pectoris, these agents are also known to increase the peripheral vascular resistance and left ventricular end diastolic pressure, which causes increases in myocardial oxygen demand. ${ }^{4}$ Furthermore, blockade of the vasodilative beta receptors on the coronary arteries would result in the unmasking of alpha mediated vasoconstrictor activity 22-24 and hence reduce coronary blood flow. ${ }^{1325}$ Alpha adrenoceptor blocking agents increase coronary blood flow and reduce coronary 122426 and peripheral vascular resistance and cause a fall in arterial blood pressure. ${ }^{9}$ Labetalol is a unique compound which possesses both non-selective beta receptor and alpha ${ }_{1}$ receptor blocking properties. It therefore produces all the beneficial effects of pure alpha blockers on the coronary and peripheral vasculature, but the tachycardia is blocked by beta receptor blockade. In isolated tissue preparation, labetalol is 4-8 times more potent in blocking beta receptors than alpha receptors. ${ }^{9}$ Patients with hyper- tension and angina pectoris have shown improvement in exercise capacity at a dose of labetalol which has ranged from 300 to $1600 \mathrm{mg} /$ day. ${ }^{5616-20}$ In this study we performed dose titration and found that the effective antianginal action of labetalol was evident at a mean daily dose of 480 (140) $\mathrm{mg} /$ day, a dose considerably lower than that in the hypertensive group of patients. The reduction in daytime heart rate of the patients in this study was comparable to the reduction seen in the hypertensive patients, ${ }^{6}$ although the reduction in arterial blood pressure in our patients was less pronounced. It is likely, therefore, that normotensive patients with myocardial ischaemia require lower doses of labetalol for therapeutic effect than patients who have hypertension.

All patients in this study had a history of chronic stable exertional angina pectoris. None had a history of frequent rest pain, and no episodes of nocturnalST segment change were noted. Thus the theoretical benefit of coronary vasodilatation with an alpha receptor antagonist could not be established convincingly in this group of patients. Comparison with a pure beta adrenoceptor antagonist, particularly in patients with angina at rest, is necessary to show any increased benefit with a combined alpha and beta receptor antagonist such as labetalol.

During exercise testing the heart rate, blood pressure, and the rate-pressure product were all lower with labetalol than with placebo even at the lowest dose of $200 \mathrm{mg} /$ day. Nevertheless, a significant increase in the duration of exercise was noted only at a higher dose of $400 \mathrm{mg} / \mathrm{day}$ and a significant antianginal effect was evident with a mean dose of 480 (140) $\mathrm{mg} /$ day of labetalol. These findings of a significant haemodynamic effect at relatively low doses and antianginal action at a relatively higher dose have also been reported in patients who have angina and hypertension. ${ }^{6}$

Although the heart rate and blood pressure at all stages of exercise were lower with labetalol, a reduction in the rate of increase of heart rate was observed only after six minutes of exercise. The effect on arterial blood pressure at different stages of exercise is difficult to determine in this study since a few patients had a fall in blood pressure towards the later stages of exercise when they were receiving placebo. There was no significant difference between the magnitude of the increase in systolic blood pressure at the termination of the exercise test when compared with placebo, although the patients had exercised longer at the higher doses of labetalol. These results contrast with the findings in patients with hypertension. ${ }^{6}$

In this study two important aspects of the use of labetalol in normotensive patients with angina pectoris were investigated for the first time. Firstly, the effective dose of labetalol was determined in each 
individual by graded dose titration, and the optimum dose was then compared with placebo in a double blind study. Secondly, the frequency of myocardial ischaemic episodes was determined both subjectively (angina diaries) and objectively by ambulatory ST segment monitoring. This showed that the frequency and duration of both painful and painless episodes of reversible ST segment depression were reduced by labetalol at a mean dose of $480(140) \mathrm{mg} /$ day. Care was taken to ensure that ST segment monitoring was performed during days when the patients underwent their normal daily activities. Therefore, not only was the effectiveness of labetalol in increasing exercise capacity demonstrated during conventional exercise tests, but there was also objective evidence of improvement in both symptomatic and asymptomatic episodes of myocardial ischaemia. This study shows that labetalol is an effective antianginal agent in patients with obstructive coronary artery disease. It has certain theoretical advantages over conventional beta adrenoceptor antagonists, and the clinical relevance of these needs to be investigated in future comparative studies.

We thank the British Heart Foundation for their support.

\section{References}

1 Thadani U, Davidson C, Singleton W, Taylor SH. Comparison of five beta-adrenoreceptor antagonists with different ancillary properties during sustained twice daily therapy in angina pectoris. $A m \mathcal{F} M e d 1980 ; 68: 243-50$.

2 Gorlin $R$. Role of coronary vasospasm in the pathogenesis of myocardial ischemia and angina pectoris. Am Heart f 1982; 103: 598-603.

3 Maseri A, Severi S, De Nes M, et al. 'Variant' angina: one aspect of a continuous spectrum of vasospastic myocardial ischemia. Am $\mathcal{F}$ Cardiol 1978; 42: 1019-35.

4 Hillis LD, Braunwald E. Coronary-artery spasm. N Engl f Med 1978; 299: 695-702.

5 Opie LH, White D, Lee J, Lubbe WF. Alternatives to beta blockade in therapy of hypertension with angina pectoris: role of nifedipine or of labetalol. $\mathrm{Br} \mathcal{F}$ Clin Pharmacol 1982; 13: 115-22S.

6 Frishman WH, Strom JA, Kirschner M, et al. Labetalol therapy in patients with systemic hypertension and angina pectoris: effects of combined alpha and beta adrenoceptor blockade. Am $\mathcal{F}$ Cardiol 1981; 48: 917-28.

7 Moyer JH, Caplovitz C. The clinical results of oral and parenteral administration of $2-\left(N^{\prime} p\right.$ Tolyl-N'-m Hydroxyphenylaminomethyl) imidazoline hydrochloride (Regitine) in the treatment of hypertension and an evaluation of the cerebral hemodynamic effects. Am Heart $\mathcal{f}$ 1953; 45: 602-10.

8 Beilin LJ, Juel-Jensen BE. Alpha and beta adrenergic blockade in hypertension. Lancet 1972; i: 979-82.

9 Brittain RT, Levy GP. A review of the animal pharmacology of labetalol, a combined alpha-and betaadrenoceptor-blocking drug. Br f Clin Pharmacol 1976;
3 (suppl 3): 681-94.

10 Richards DA. Pharmacological effect of labetalol in man. Br $\mathcal{F}$ Clin Pharmacol 1976; 3 (suppl 3): 721-3.

11 Baum T, Sybertz EJ. Pharmacology of labetalol in experimental animals. Am $\mathcal{F}$ Med 1983; 75 (suppl 4A): 15-23.

12 Mehta J, Feldman RL, Marx JD, Kelly GA. Systemic, pulmonary and coronary hemodynamic effects of labetalol in hypertensive subjects. Am F Med 1983; 75 (suppl 4A): 32-9.

13 Frishman W, Halprin S. Clinical pharmacology of the new beta-adrenergic blocking drugs. Part 7. New horizons in beta-adrenoceptor blockade therapy: labetalol. Am Heart f 1979; 98: 660-5.

14 Davidov ME, Moir GD, Poland MP, Maloy J, Medakovic M. Monotherapy with labetalol in the treatment of mild hypertension: a double-blind study. $A m \mathcal{F}$ Med 1983; 75 (suppl 4A): 47-53.

15 Frishman WH, Michelson EL, Johnson BF, Poland MP. Multiclinic comparison of labetalol to metoprolol in treatment of mild to moderate systemic hypertension. Am $\mathcal{F}$ Med 1983; 75 (suppl 4A): 54-67.

16 Prichard BN, Boakes AJ. Labetalol in long-term treatment of hypertension. Br $\mathcal{F}$ Clin Pharmacol 1976; 3 (suppl 3): 743-50.

17 Lubbe WF, White DA. Beneficial effect of labetalol in hypertensive patients with angina pectoris. $S$ Afr Med $\mathcal{F}$ 1983; 63: 67-71.

18 Boakes AJ, Prichard BN. The effect of AH5158, pindolol, propranolol, D-propranolol on acute exercise tolerance in angina pectoris. $\mathrm{Br} \mathcal{F}$ Pharmacol 1973; 47: 673-4P.

19 Besterman EMM, Spencer M. Open evaluation of labetalol in the treatment of angina pectoris occurring in hypertensive patients. $\mathrm{Br} \mathcal{F}$ Clin Pharmacol 1979; 8: 205-9S.

20 Nyberg G, Bjurö T, Hagman M, Smith U. Relation between ST-depression and chest pain in patients with coronary heart disease receiving no treatment and after beta-blockade and combined alpha-beta-blockade. Acta Med Scand 1981; (suppl 644): 30-3.

21 Bruce RA. Multistage treadmill tests of submaximal and maximal exercise. In: American Heart Association Committee on Exercise. Exercise testing and training of apparently healthy individuals: handbook for physicians. New York: American Heart Association, 1972: 32-4.

22 Rubio R, Berne RM. Regulation of coronary blood flow. Prog Cardiovasc Dis 1975; 18: 105-22.

23 Braunwald E. Coronary spasm and acute myocardial infarction-new possibility of treatment and prevention. N Engl f Med 1978; 299: 1301-3.

24 Orlick AE, Ricci DR, Alderman EL, Stinson EB, Harrison DC. Effects of alpha adrenergic blockade upon coronary hemodynamics. 7 Clin Invest 1978; 62: 459-67.

25 Lund-Johansen P. Comparative haemodynamic effects of labetalol, timolol, prazosin and the combination of tolamolol and prazosin. Br f Clin Pharmacol 1979; 8: 107-11S.

26 Gagon RM, Morissette M, Présant S, Savard D, Lemire J. Hemodynamic and coronary effects of intravenous labetalol in coronary artery disease. Am $\mathcal{F}$ Cardiol 1982; 49: 1267-9. 